\title{
Comparative analysis of preparation of human hepatocytes by the ethylenediamine tetraacetic acid and collagenase technique ${ }^{1}$
}

\author{
Estudo comparativo da obtenção de hepatócitos humanos pela técnica ácido \\ etilenodiaminotetracético e da colegenase
}

\author{
Eduardo Crema², Ana Márcia Werneck ${ }^{3}$, Aiodair Martins Júnior ${ }^{4}$, Lara Beatriz Prata Ribeiro ${ }^{5}$, Tatiana Silva de Lima ${ }^{5}$, \\ Alex Augusto Silva ${ }^{6}$
}

1. Research performed at Experimental Laboratory Tecnique of Surgery, Department of Surgery, Federal University of Triângulo Mineiro (UFTM), Brazil.

2. MD, PhD, Department of Digestive Surgery, UFTM, Brazil.

3. Resident, UFTM, Brazil.

4. MD, Department of Digestive Surgery, UFTM, Brazil.

5. Graduate student, UFTM, Brazil.

6. MD, Head of the Department of Digestive Surgery, UFTM, Brazil.

\begin{abstract}
Purpose: To compare the viability of human hepatocytes dissociated by the ethylenediaminetetraacetic acid and collagenase techniques. Methods: Hepatocytes were prepared by dissociation of liver fragments obtained from hepatectomies performed for therapeutic purposes at the Service of Digestive Tract Surgery, Federal University of Triângulo Mineiro. Results: During the first 4 days of the experiment, 70\% of the cells presented birefringent membranes and were not stained with $2 \%$ erythrosine, and were therefore considered to be viable. During the first 3 days, hepatocyte viability was on average $71 \%$ in the EDTA group and $76 \%$ in the collagenase group, with no significant difference between groups. No significant difference was observed between groups at any time. The secretion of albumin by the cultured hepatocytes was preserved up to the seventh day. Mean albumin secretion during the first 3 days was $50 \mu \mathrm{g} / \mathrm{ml}$ in the two groups and a reduction of albumin production was observed from the fourth to the seventh day. Again, no significant difference was observed between groups at any time. Conclusion: Cell viability and preservation of albumin secretion by hepatocytes are similar for the EDTA and collagenase techniques.
\end{abstract}

Key words: Cell Separation. Cell Transplantation. Edetic Acid.

\section{RESUMO}

Objetivo: Comparar a viabilidade dos hepatócitos humanos dissociados pelas técnicas do ácido etilenodiaminotetracético e da colagenase. Métodos: Hepatócitos foram preparados pela dissociação de fragmentos de fígado, provenientes de hepatectomias realizadas com o objetivo terapêutico no Serviço de Cirurgia do Aparelho Digestivo da Universidade Federal do Triângulo Mineiro. Resultados: Detectou-se que nos quatro primeiros dias de experimento $70 \%$ das células estavam com suas membranas biorrefringentes e não se coravam pela eritrosina a $2 \%$ portanto foram consideradas viáveis. Observou-se que nos três primeiros dias a viabilidade dos hepatócitos foi em média $71 \%$ no grupo EDTA e $76 \%$ na colagenase, diferença esta sem significado estatístico entre os grupos. Em nenhum momento, detectou-se diferença estatística entre os grupos. Com relação a preservação da secreção de albumina pelos hepatócitos em cultura observouse que foi mantida até o sétimo dia. Da mesma forma, notou-se que nos três primeiros dias a média de secreção de albumina de ambos os grupos foi de 50 ìg/dl e que após o quarto dia verificou-se redução da produção até o sétimo dia. Também não foi observado diferença significativa em nenhum momento entre os grupos. Conclusão: A viabilidade celular e a preservação da função de secretar albumina pelos hepatócitos são semelhantes pelas técnica do EDTA e da colagenase.

Descritores: Separação Celular. Transplante de Células. Ácido Edético.

\section{Introduction}

Several research centers have been searching for auxiliary liver transplantation techniques either for definitive use in chronic or temporary situations or for acute situations, thus prolonging the waiting time for functional improvement of the regenerated liver or for appearance of a compatible liver transplant donor, with the latter certainly continuing to be the only therapy for end-stage hepatic insufficiency and metabolic disorders. The great expectation of finding a bioartificial liver has directed research at the utilization of isolated viable hepatic cells with preserved functions ${ }^{1,2,3}$. Sun ${ }^{4}$, using a semipermeable alginate-polylysine membrane for the 
microencapsulation of hepatocytes, reported satisfactory viability of the cells in vitro and in vivo ${ }^{5}$. Several investigators studying the preservation of hepatocyte function in homozygous Gunn rats noted a significant reduction of bilirubin levels over a period of 30 days when intraperitoneally transplanted microencapsulated hepatocytes were used ${ }^{6}$. Immunoprotection offered by the microcapsule membrane, as well as a significant reduction of bilirubin levels, has been demonstrated in Gunn rats receiving alginate-polylysinemicroencapsulated hepatocytes ${ }^{6}$. The most commonly used methods for the dissociation of hepatocytes from other types of cells (biliary cells, supporting cells, vascular cells, etc.) without compromising their metabolic functions are EDTA (ethylenediamine tetraacetic acid) or collagenase perfusion, or a combination of both. Therefore, the objective of the present study was to compare the viability of human hepatocytes dissociated by the EDTA and collagenase techniques.

\section{Methods}

To compare the dissociation of hepatocytes by the EDTA and collagenase techniques, hepatocytes were prepared by dissociation of liver fragments obtained from hepatectomies performed for therapeutic purposes at the Service of Digestive Tract Surgery, Federal University of Triangulo Mineiro (UFTM). All patients gave free informed consent to participate and the study was approved by the Ethics Committee of UFTM.

\section{Dissociation of human liver fragments by the EDTA method}

Hepatocytes were prepared by dissociation of a liver fragment with EDTA. The perfusion solution had the following composition ${ }^{7}$ : $140 \mathrm{mM} \mathrm{NaCl}, 5 \mathrm{mM} \mathrm{KCl}, 0.8$ $\mathrm{mM} \mathrm{MgSO}_{4} 1.6 \mathrm{mM} \mathrm{Na}_{2} \mathrm{HPO}_{4} 0.4 \mathrm{mM} \mathrm{KH}_{2} \mathrm{PO}_{4} 2 \mathrm{mM}$ EDTA, and $25 \mathrm{mM} \mathrm{NaHCO}$. The EDTA solution was perfused through small catheters placed in the venous segments and fixed with 4.0 Prolene sutures at a constant temperature of $37^{\circ} \mathrm{C}$. A perfusion pump was used to guarantee continuous perfusion for 30 to $40 \mathrm{~min}$ at a constant flow rate of 3 to $4 \mathrm{ml} / \mathrm{kg}$ liver fragment $/ \mathrm{min}$. After perfusion, the liver fragment was placed in a 50-ml sterile glass container (Becker) filled with $20 \mathrm{ml}$ HAM"S 12 culture medium at $4^{\circ} \mathrm{C}$ and carefully cut until only small fragments were left. This suspension was then filtered through gauze bandage. The suspension obtained was ultracentrifuged twice at $5000 \mathrm{rpm}$ for $2 \mathrm{~min}$. The supernatant was aspirated and discarded and the cell mass obtained was weighed. Hepatocytes were separated on a pressure gradient by adding one volume of Percoll solution at a concentration of $1 / 10$, using a proportion of $1 \mathrm{~g}$ cell mass for each $4 \mathrm{ml}$ of Percoll solution. This solution was centrifuged at $6000 \mathrm{rpm}$ for $5 \mathrm{~min}$. Hepatocytes were counted in a Nageotte chamber. Cell viability was evaluated by determining membrane birefringence and by the $2 \%$ erythrosine exclusion test, and the results are expressed as percentage of viable cells.

\section{Dissociation of human liver fragments by the collagenase technique}

The method of in situ perfusion with collagenase described by Berry and Friend ${ }^{8}$ and modified by Guilouzo ${ }^{9}$ was used, which differs from the EDTA method in terms of the solutions employed and the time of perfusion. Perfusion solution - washing at a flow rate of $30 \mathrm{ml} / \mathrm{min}$ for $15 \mathrm{~min}: 160.8 \mathrm{mM} \mathrm{NaCl}, 3.15 \mathrm{mM} \mathrm{KCl}, 0.7 \mathrm{mM} \mathrm{Na}_{2} \mathrm{HPO}_{4}$ . $12 \mathrm{H}_{2} \mathrm{O}, 33 \mathrm{nM}$ Hepes (N-[2-hydroxyethyl] piperazine-N[2-ethanesulfonic acid]). Perfusion solution - dissociation at a flow rate of $15 \mathrm{ml} / \mathrm{min}$ for $20 \mathrm{~min}: 160.8 \mathrm{mM} \mathrm{NaCl}, 3.15$ $\mathrm{mM} \mathrm{KCl}, 0.7 \mathrm{mM} \mathrm{Na}_{2} \mathrm{HPO}_{4}$. 12 $\mathrm{H}_{2} \mathrm{O}, 33 \mathrm{mM}$ Hepes, 0.075 $\mathrm{mM} \mathrm{CaCl}$, and $0.05 \%$ collagenase D.

\section{Hepatocyte culture}

The cells obtained with the two dissociation techniques were cultured in medium consisting of mixture of 75\% Williams E (Gibco) and 25\% Leiba 15 medium enriched with $100 \mathrm{mg} / \mathrm{ml}$ bovine serum albumin, $0.1 \mathrm{U} / \mathrm{ml}$ insulin, $30 \mathrm{IU} / \mathrm{ml}$ crystalline penicillin $\mathrm{G}, 100 \mathrm{mg} / \mathrm{ml}$ streptomycin, and $10 \%$ fetal bovine serum. The $\mathrm{pH}$ was adjusted to 7.4 with $2.2 \mathrm{mg} / \mathrm{ml}$ sodium carbonate. After 4 to $6 \mathrm{~h}$ of incubation at $37^{\circ} \mathrm{C}$ in a humid atmosphere $(95 \%$ air and $5 \% \mathrm{CO}_{2}$ ), the hepatocytes were found to be adhered to the bottom of the plate. The culture medium was then aspirated and replaced with the same fresh medium supplemented with hydrocortisone semisuccinate at a proportion of $4.5 \times 10^{5} \mathrm{mg} / \mathrm{ml}$. This medium was changed daily until the end of the experiment. The hepatocytes obtained were cultured on $5-\mathrm{cm}$ plastic Petri dishes in medium at a proportion of $1.5 \times 10^{5}$ cells/ $\mathrm{cm}^{2}$. Twenty-eight Petri dishes, including 14 for hepatocytes obtained by EDTA dissociation and 14 for hepatocytes obtained by the collagenase technique, were used.

Analysis of the preservation of albumin secretion by hepatocytes obtained with the EDTA and collagenase methods

The presence of human albumin was determined in the culture supernatant obtained daily from the 28 Petri dishes. Albumin was assayed in the aspirated culture medium using an antigen specific for the detection of human albumin, thus preventing contamination with the bovine albumin used in the preparation of the culture medium.

\section{Results}

Hepatocyte viability was compared daily in two plates from each group for a period of 7 days. The results showed that, during the first 4 days of the experiment, $70 \%$ of the cells presented birefringent membranes and were not stained with $2 \%$ erythrosine, and were therefore considered to be viable. During the first 3 days, hepatocyte viability was on average $71 \%$ in the EDTA group and $76 \%$ in the collagenase group, with no significant difference between groups. An expressive 
reduction of cell viability was observed after the fifth day for both techniques, affecting the rates of viable cells. No significant difference was observed between groups at any time (Figure 1). The secretion of albumin by the cultured hepatocytes was preserved up to the seventh day. Mean albumin secretion during the first 3 days was $50 \mu \mathrm{g} / \mathrm{ml}$ in the two groups and a reduction of albumin production was observed from the fourth to the seventh day. Again, no significant difference was observed between groups at any time (Figure 2).

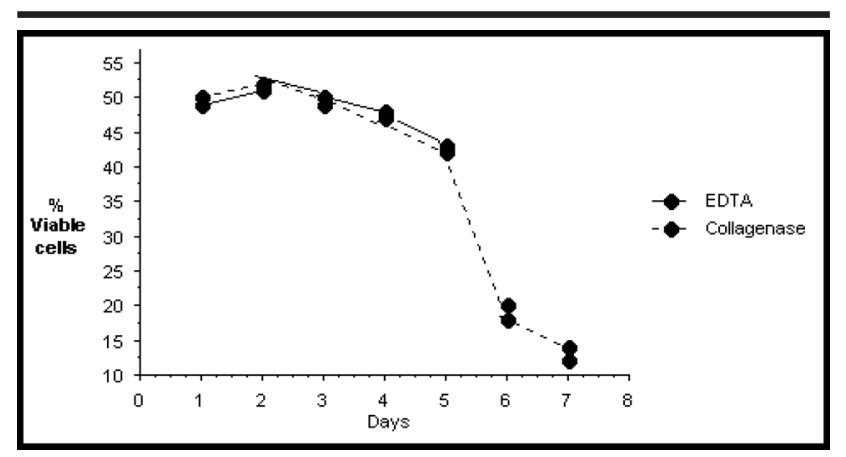

FIGURE 1 - Viability of isolated cultured hepatocytes obtained by EDTA and collagenase dissociation.

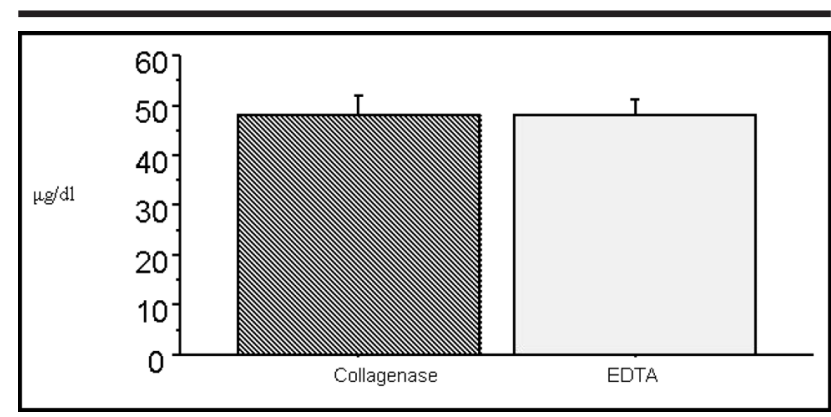

FIGURE 2 - Mean albumin secretion by the cultured hepatocytes $(\mu \mathrm{g} / \mathrm{dl})$

\section{Discussion}

Liver transplantation has undergone great advances since 1963 when Starzl in the United States proposed homotransplantation of the liver in humans, a procedure which continues to be the only effective technique for functional replacement of the liver until today. Despite the advances in transplantation techniques, better immunosuppressive agents and improved care during postoperative recovery, 20 to $30 \%$ of patients with hepatic insufficiency continue to die while on the waiting list, mainly because of the small number of donors. In this respect, over the last few years, the development of a bioartificial liver or of viable hepatic cell transplants has raised the interest of several research centers in an attempt to temporarily replace the failing liver, maintaining the patient alive until a compatible donor is found, or even to replace treat isolated metabolic disorders ${ }^{10,11}$. To obtain isolated cells with preserved functions, it is necessary to dissociate the hepatocytes from the liver to separate them from biliary, vascular and connective tissues which are often responsible for rejection of the organ. There are still no standardized liver dissociation techniques; however, all techniques propose the perfusion of solutions through the portal vein ${ }^{5}$ in intact livers or small liver fragments ${ }^{11,12}$, with the methods differing in terms of the solution used for perfusion witch EDTA $^{7}$, hyaluronidase, collagenase or a combination of these solutions ${ }^{13}$. In the present study, cell viability was $85 \%$ and $83 \%$ after dissociation with EDTA and collagenase, respectively, rates higher than those reported by other investigators ${ }^{14}$. Up to the third day, mean viability was found to be similar for the two techniques and a marked quantity of viable hepatocytes was observed, which might be used in hemodialyzers or in studies on new drugs or cellular genetic modifications $2,9,15$. The present results were similar to those reported in previous studies employing in situ dissociation of rat livers. Cell viability was excellent and no difference was observed between dissociation with EDTA and collagenase. We therefore recommend the use of EDTA as a dissociation solution because of its much lower cost compared to collagenase. Another advantage of EDTA is that its action is interrupted at the end of dissociation, in contrast to collagenase, thus preserving cellular functions.

\section{Conclusion}

Based on the present experiment we conclude that cell viability and preservation of albumin secretion by hepatocytes are similar for the EDTA and collagenase techniques.

\section{Reference}

1. Kobayashi N, Miyazake M, Fukaya K, Inoue Y, Sakaguchi M, Uemura T, Noguchi H, Kondo A, Tanaka N, Namba M. Transplantation of highly differentiated immortalized human hepatocytes to treat acute liver failure. Transplantation. 2000; (2): 202-8.

2. Ribeiro J, Ballet, F., Panis, Y, Delelo R, Legendre C, Nordlinger, B. Intrasplenic hepatocellular transplantation corrects hepatic encephalopathy in portacaval shunted rats. Hepatology. 1992; 15 (1): 1-6.

3. Sarkis R, Benoist S, Honiger J, Baudrimont M, Delelo R, Balladur P, Capeau J, Nordlinger B. Transplanted cryopreserved encapsuled porcine hepatocytes are as effective as fresh hepatocytes in preventinh death from cute failure in rats. Transplantation. 2000; (70): 58-64.

4. Sun AM, Cai Z, Ma ., O'Shea GM, Ghanapetian H. Microencapsuled hepatocytes as a bioartificial liver. Trans. Am. Soc. Artif. Intern. Organs. 1986; (32): 39-41.

5. Demetriou AA, Reisner A, Salmirez J, Levenson SM, Moscioni AD, Chowdhury, JR. Transplantation of microcarriers-attached hepatocytes into $90 \%$ partially hepatectomized rats. Hepatology. 1988; (8):1006-9.

6. Dixit V, Darvasi R, Arthur M, Lewin KJ, Gitnick G. Improved function of microencapsulated hepatocytes in a hybrid bioartificial liver support system. Artif Organs. 1992; (16): 336-41. 
7. Balladur P, Crema E, Honiger J, Calmus Y, Baudrimont M, Deleto R, Capeau J, Nordlinger B. Transplantation of allogeneic hepatocytes without immunosuppression: long-term survival. Surgery. 1995; (117): 189-4.

8. Wang SR., Renaud G, Infante J, Catala D, Infante R. Isolation of rat hepatocytes with EDTA and their metabolic function in primary culture. In Vitro. 1985; (21): 526-30.

9. Berry MN, Friends DS. Hig yield preparation of isoled rat liver parenchymal cells: a biochemical and fine structural study. J. Cell. Biol. 43: 506-20, 1969.

10. Guillouzo GC, Guillouzo A. Modulation of functional activites in cultured rat hepatocytes. Mol. Cell. Biochem. 1983; (53): 35-40.

11. Soriano HE, Wood RP, Kang DC, et al. Hepatocellular transplantation (HCT) in children with fulminant liver failure (FLF). Hepatology. 1997; (26): 239-43.
12. Strom SC, Fisher RA, Rubinstein WS, Barranger JA, Towbin RB, Charron M, Mieles L, Pisarov RA, Dorko K, Thompson MT, Reyes J. Transplantation of human hepatocytes. Transplant Proc. 1997; (29): 2103-6.

13. Strom SC, Jirtle RL, Jones RS e cols. Isolation, culture and transplantation of human hepatocytes. J. Natl. Cancer Inst. 1982; 68(5): 771-8.

14. Gerlach JC, Brombacher J, Kloppel K e Cols. Comparison of four methods for mass hepatocyte isolation from pig and human livers. Transplantation. 1994; 57(9):1318-22.

15. Haschtmann D, Gerber HJ, Mielke ME. Cytotoxix qctivity of murine resident peritoneal cells against Listeria monocytogenes-infecte hepatocytes in vitro. Microbes Infect. 2005; 7(11): 1177-83.

16. Bulla GA, Kraus DM. Dissociation of the hepatic phenotype from HNF4 and HNF1 alpha expression. Biosci Rep. 2004; 24(6): 595-608.

\section{Correspondence:}

Eduardo Crema

Rua Marcos Lombardi, 305

38050-170 - Uberaba - MG - Brazil

Phone: (55 34)3315-4500

Fax:(5534)-3318-528

e-mail: cremauftm@mednet.com.br
Conflict of interest: none Financial source: Research Foundation of Minas Gerais

Received: August 15, 2006

Review: September 12, 2006

Accepted: October 10, 2006

\section{How to cite this article:}

Crema E, Werneck AM, Martins JR A, Ribeiro LBP, Lima TS, Silva AA. Comparative analysis of preparation of human hepatocytes by the ethylenediamine tetraacetic acid and collagenase technique. Acta Cir Bras. [serial on the Internet] 2007 Jan-Feb;22(1). Available from URL: http://www.scielo.br/acb. 